\title{
HAMBRE, REVOLUCIÓN Y DERROTA: EL CINEMA NOVO Y LOS DESENCUENTROS DE LA MODERNIDAD LATINOAMERICANA
}

\author{
Mónica González García \\ Universidad de Talca \\ mogonzalez@utalca.cl
}

\section{RESUMEN / RESUMO / ABSTRACT}

En este ensayo recorro diversas películas del Cinema Novo brasileño de la década de 1960, a partir de los conceptos hambre, revolución y derrota, para examinar lo que describo como el último gran desencuentro de la modernidad en América Latina -a saber, el fin de las utopías redentoras de izquierda. Según explico, en ciertas obras cinematográficas de esta década es posible hallar claves del profundo cambio que experimentó el campo cultural brasileño, donde la introducción de la violencia de la "dialéctica de la marginalidad" (Castro Rocha) fue superada por la jovialidad de la "dialéctica del malandrinaje" (Candido). No obstante, esta vez el malandrinaje trajo consigo la mediación "cordial" del mercado. Mi análisis, centrado principalmente en películas de Nelson Pereira dos Santos, Glauber Rocha y Joaquim Pedro de Andrade, busca leer los cambios sintomatizados por el Cinema Novo de la década de 1960 como sinécdoque de transformaciones culturales similares en el resto de América Latina.

Palabras clave: Cinema Novo, campo cultural, década de 1960, malandrinaje, marginalidad.

Neste ensaio, percorro diversos filmes do Cinema Novo brasileiro da década de 1960, a partir dos conceitos da fome, revolução e derrota, para examinar o que descrevo como o último grande desencontro da modernidade na América Latina - a saber, o fim das utopias redentoras da esquerda. De acordo com meu argumento, em certas obras cinematográficas dessa década, é possivel identificar sinais da profunda mudança experimentada pelo campo cultural brasileiro, onde a introdução da violência da "dialética da marginalidade" (Castro Rocha) foi superada pela jovialidade da "dialética da malandragem" (Candido). No entanto, desta vez a malandragem trouxe consigo a mediação "cordial" do mercado. Minha análise, focado principalmente nos filmes de Nelson Pereira dos Santos, Glauber Rocha e Joaquim 
Pedro de Andrade, busca ler as mudanças sintomatizadas pelo Cinema Novo da década de 1960 como sinédoque de transformações culturais similares no resto da América Latina.

PALAVRAS-CHAVE: Cinema Novo, campo cultural, década de 1960, malandragem, marginalidade.

This essay analyzes several films from the 1960s Cinema Novo movement in Brazil. These observations are focused on the concepts of hunger, revolution and defeat, and evaluate what I describe as the last great clash of modernity in Latin America, namely, the end of redemptive left-wing utopia. As I argue it is possible to identify signs of profound cultural change in Brazil in certain films made in that decade, in which the violence present in Castro Rocha's "dialectics of marginality" was overcome by the playfulness of Antonio Candido's "dialectics of roguery". However, this time, "roguery" brought along the "cordial" mediation of the market. This analysis, focused primarily on the films by Nelson Pereira dos Santos, Glauber Rocha, and Joaquim Pedro de Andrade, seeks to point out the changes portrayed in the $1960 \mathrm{~s}$ Cinema Novo as a synecdoche of similar cultural transformations in the rest of Latin America.

KEYWORDS: Cinema Novo, cultural field, decade of the 1960s, malandroism, marginality.

Visto a la distancia, el Cinema Novo de la década de 1960 pareciera poseer el raro perfil de un abanico de propuestas que concentra vida, fulgor y muerte de las luchas sociales latinoamericanas del siglo XX. Quizás por su estrecho diálogo con las literaturas modernista y regionalista, en muchas de estas películas es posible vislumbrar transformaciones cruciales del campo cultural brasileño e incluso extrapolar sus efectos para el resto de América Latina. A modo de arco metodológico, y en conversación con los tres momentos que Randal Johnson y Robert Stam sugieren para recorrer el Cinema Novo -fases optimista inicial, menos utópica y alegórica tropicalista (133)-, en este trabajo analizamos las variables hambre, revolución y derrota para trazar una trayectoria posible del proyecto de modernidad sostenido por las izquierdas latinoamericanas y adherido por la mayor parte de los directores del Cinema Novo. El hambre, visto como consecuencia del colonialismo o la dependencia, es uno de los motores sociales que anima las demandas políticas del siglo XX, reunidas bajo el paradigma de la revolución, utopía que hacia fines de la década en análisis muestra signos inminentes de derrota con la proclamación del Acto Institucional 5 durante la dictadura de Artur da Costa e Silva y la muerte del Che Guevara, ambos hechos ocurridos en 1968. En este contexto, tomado como espacio de disputas ideológicas y epistemológicas según la conceptualización de Pierre Bourdieu, o como un espacio de guerras discursivas según el corolario de Néstor García Canclini, la noción de campo cultural nos parece una matriz pertinente para el examen 
de esta suerte de clarividencia sinóptica del Cinema Novo brasileño en torno a la introducción de nuevos habitus que transformarían la doxa renovando los privilegios de clases dominantes locales y globales ${ }^{1}$.

En Brasil, la irrupción de este espacio público de disputas ideológicas, que también dio origen a los principales símbolos del imaginario cultural del siglo XX, ocurre durante la matanza de Canudos, primer gran desencuentro de la modernidad republicana en tanto revela las astronómicas deudas sociales con las que se transitó del Imperio a la República. En este episodio, registrado por la prosa sintomáticamente tensa de Euclides da Cunha en Os Sertões (1902), surgen como nunca antes en el mundo lusoamericano -parafraseando el análisis de Julio Ramos sobre las regiones hispanoparlantes del continente en el siglo XIX- "nuevos sujetos intelectuales, nuevas posiciones y lugares de enunciación, discursos e instituciones del saber", así como otros "discursos... sobre la modernidad" (45). Uno de los sujetos que emerge en esta nueva configuración cultural es Euclides da Cunha, quien como corresponsal de $O$ Estado de São Paulo viajó al interior del sertão bahiano para registrar la esperada derrota de los rebeldes monarquistas que se oponían a la declaración de la República. Como han notado muchos críticos, uno de los trazos más sobresalientes de Os Sertões es el tránsito progresivo de la palabra de da Cunha a una "nueva posición" ciertamente crítica de la cultura que esa modernidad republicana pretendía imponer a fuerza de balas entre los hambrientos sertanejos seguidores del líder carismático Antonio Conselheiro. Habiendo llegado al sertão de Bahía como creyente en las teorías spencerianas sobre la anomalía de razas bárbaras como la sertaneja y como defensor de la modernidad republicana -"estamos condenados a la civilización. O progresamos o desaparecemos" (47)-, el cronista acaba comprendiendo la visión de mundo del hombre rural: "Aislados en el espacio y en el tiempo, los jagunços, un anacronismo étnico, sólo podían hacer lo que hicieron, vencer terriblemente a la nacionalidad que, después de abandonarlos cerca de tres siglos, quería arrastrarlos a los deslumbramientos de nuestra edad dentro de un corral de bayonetas, mostrándoles el brillo de la civilización a través de la claridad de las descargas" (230). Este cambio de posición anticipa al

\footnotetext{
Nos interesa la relación entre obra de arte y campo cultural porque, según Pierre Bourdieu, "comprender una obra de arte sería comprender la visión del mundo propia del grupo social a partir o para el cual el artista habría compuesto su obra, y que [...] se habría expresado en cierto modo a través del artista" (303). En este campo cultural es donde se da lo que García Canclini llama "guerra de relatos" (cit. en Rocha 31).
} 
intelectual comprometido del siglo XX latinoamericano, quien, usualmente de sectores acomodados, opta por "matar al padre" para apoyar las luchas sociales desde la política partidista y/o desde el arte y la literatura ${ }^{2}$.

Dos décadas después de la publicación de Os Sertões,y adoptando el espíritu revolucionario y lúdico de las vanguardias europeas, varios jóvenes paulistas se ocuparon de alegorizar los debates sobre la nacionalidad y la modernidad en obras literarias como Macunaíma (Mário de Andrade) y el Manifesto Antropofágico (Oswald de Andrade), ambas de 1928. El desencanto europeo con la modernidad ilustrada y la consecuente valoración artística de culturas no-occidentales -con corrientes como el primitivismo y el nativismo-influyó en la relectura que los modernistas brasileños hicieron de su propio territorio. "Queremos la Revolución Caraíba. Mayor que la Revolución Francesa", dice Oswald, mientras Mário crea un héroe sin carácter que recorre la geografía, las culturas y las razas de Brasil en busca de la clave de la nacionalidad. El itinerario épico de Macunaíma, del corazón amazónico a la ciudad moderna, São Paulo, y de allí a Europa, es un guiño burlesco a los intelectuales que, aquejados por "el mal de Nabuco", siguen buscando en Europa las claves de la modernidad nacional. La falta de carácter del héroe ficcional de Mário de Andrade se emparienta con el arquetipo sociológico distinguido por Sérgio Buarque de Holanda en su estudio Raizes do Brasil (1936), donde ofrece una de las construcciones más populares para explicar la prevalencia de formas premodernas en la sociedad brasileña: el hombre cordial. Definido como la contribución brasileña a la civilización, el "hombre cordial" se caracteriza por "la hospitalidad [y] la generosidad" (146), virtudes que no obstante derivan de "patrones de convivencia informados en el medio rural y patriarcal" y, por tanto, contrarias a la idea moderna de individuo. João César de Castro Rocha explica que la cordialidad implica una aversión a dejar de ser "persona" para convertirse en "individuo" (34), temor que ciertamente inspiró un tipo de

2 La idea moderna del intelectual comprometido convencionalmente parte con Émile Zola y su carta al presidente de la república "J'Accuse" (1898) a favor de Alfred Dreyfus, acusado injustamente de espionaje. Otro hito que marca el siglo XX en este sentido es la idea de Jean-Paul Sartre del intellectuel engagé, desarrollada particularmente en su libro Qu'est-ce que la littérature? (1948), a propósito de las guerras mundiales. Sin dejar de tomar en cuenta estos hitos, en este trabajo me interesa la tradición latinoamericana del intelectual comprometido que va, en el siglo XIX, de Francisco Bilbao a José Martí y, en el siglo XX, de Euclides da Cunha al Che Guevara -entre muchos otros-y que añade, a la diferencia "social" entre el intelectual y el pueblo, la variable "racial". 
interpretación recurrente de los héroes de la literatura brasileña: la "dialéctica del malandrinaje", óptica desde la cual Antonio Candido leyó la disyuntiva del protagonista de Memórias de um Sargento de Milícias (1852), novela de Manuel Antônio de Almeida. Para Castro Rocha, esta manera de entender los productos culturales brasileños se hizo insuficiente, para lo cual añade una fórmula más pertinente según las características de la cultura actual: la "dialéctica de la marginalidad". El crítico explica que "si la "dialéctica del malandrinaje' supone una forma relajada, jovial de lidiar con la injusticia social y lo cotidiano, la 'dialéctica de la marginalidad' se impone mediante la explotación e incluso la exposición metódica de la violencia, a fin de explicitar el dilema de la sociedad brasileña" (24). Castro Rocha dice que la emergencia de estos dos patrones de interpretación de Brasil ha creado una "batalla simbólica" en el campo cultural actual, aunque reconoce que la violencia denunciadora del "sistema social brasileño, que funciona como una perversa máquina de exclusión, bajo la apariencia de la falsa promesa de armonía" (56-57), tuvo un antecedente importante en el Cinema Novo. Por ello utilizamos estos dos modelos, la dialéctica del malandrinaje y la dialéctica de la marginalidad, para acompañar la revisión del Cinema Novo de la década de 1960 -especialmente de Nelson Pereira dos Santos, Glauber Rocha y Joaquim Pedro de Andrade-, escuela que debate con el proceso de construcción cultural del Brasil moderno que va de Os Sertões a Raízes do Brasil y del modernismo al regionalismo. Como estética politizada, el Cinema Novo cuestiona dos modelos de modernidad: en el arte, la perfección aburguesada y comercial de la estética visual de Hollywood; y en la sociedad, la imagen de Brasil como país satisfecho y moderno cristalizada con la inauguración de Brasília en 1960. A estas dos visiones "colonialistas", el Cinema Novo opone la evidenciación del miserabilismo de las favelas y el sertão.

\section{HAMBRE Y SOCIEDAD: EL PUEBLO URBANO Y RURAL INVADE LA PANTALLA GRANDE}

Iam-se amodorrando e foram despertados por Baleia, que trazia nos dentes um preá. Levantaram-se todos gritando. O menino mais velho esfregou as pálpebras, afastando pedaços de sonho. Sinha Vitória beijava o focinho de Baleia, e como o focinho estava ensanguentado, lambia o sangue e tirava proveito do beijo. Vidas secas (1938), Graciliano Ramos. 
Una de las salvedades de Castro Rocha para identificar la dialéctica de la marginalidad con el Cinema Novo es lo que ve como una obsesión con las topografías culturales del sertão, en circunstancias que los productos simbólicos contemporáneos de carácter marginal se dan en un contexto urbano. Es cierto que entre los filmes de la década de 1960 abundan desiertos y sertanejos, pero también resulta necesario cuestionar esta dicotomía excluyente de lo rural y lo urbano. En primer lugar, conviene referirse a una película que, aunque no es clasificada como Cinema Novo, es un antecedente ineludible que puede leerse según las variables del hambre propuesto más tarde por Glauber Rocha y la marginalidad definida por Castro Rocha ${ }^{3}$. Se trata de Rio, 40 graus (1955) de Nelson Pereira dos Santos, drama coral urbano que sigue a cinco niños de favela en su odisea por vender maní en los lugares turísticos de Río de Janeiro, recorrido en el cual se incorporan personajes cuyo único elemento común es habitar la misma ciudad. De manera similar a las sinfonías urbanas, Nelson Pereira dos Santos pareciera exponer sin juzgar las diferencias sociales en un montaje narrativo que no obstante desenvuelve una serie de dramas ante la mirada del espectador, como el maltrato del guardia del zoológico a Sujinho, niño huérfano cuya única compañía es la lagartija Catarina; el accidente automovilístico que provoca la muerte de Jorge, quien sale a pedir dinero para ayudar a su mamá enferma; o la peligrosa rivalidad entre Waldomiro y el "bahiano" por el amor de Alice. Lo llamativo es que la crudeza de estas imágenes es contrapunteada por el samba "A voz do morro", compuesta por Zé Keti y adaptada por Radamés Gnatalli como música incidental, con acordes y versos que inevitablemente dulcifican la pobreza que vemos:

Eu sou o samba

A voz do morro sou eu mesmo sim senhor

Quero mostrar ao mundo que tenho valor

Eu sou o rei dos terreiros

Eu sou o samba

Sou natural daqui do Rio de Janeiro

Sou eu quem leva a alegría

Para milhões de corações brasileiros

Salve o samba, queremos samba

\footnotetext{
Johnson y Stam definen el Cinema Novo como un "movimiento que buscó transformar la sociedad aplicando una visión nueva, crítica y modernista de la nación, y encontrar un nuevo lenguaje cinematográfico que reflejara la realidad brasileña" (132).
} 
Quem está pedindo é a voz do povo de um país

Salve o samba, queremos samba

Essa melodia de um Brasil feliz

El registro directo de la miseria urbana en Rio, 40 graus marca un hito en el cine brasileño por ser el primer film de ese país en ocuparse de los meninos da rua, problema tratado también por Jorge Amado en su novela Capitães da Aréia (1937). Estas "radiografías de la desigualdad" (Castro Rocha 57) provocaron airadas reacciones gubernamentales: si la novela fue perseguida por la dictadura de Getúlio Vargas, quien ordenó la quema de 800 ejemplares en la plaza de Salvador por considerarla propaganda comunista, el film fue censurado por el coronel Geraldo de Menezes Cortes durante el gobierno de Café Filho, por su supuesto financiamiento soviético. Cortes incluso declaró que la historia era una mentira porque Río de Janeiro nunca había alcanzado esa temperatura sino solo 39,6 grados. Como el drama mexicano Los olvidados (1950) de Luis Buñuel, la película de Nelson Pereira dos Santos estimuló el debate sobre la marginalidad infantil y la pobreza urbana. Sin embargo, a diferencia del film mexicano, que concluye con la muerte de Pedro en manos del Jaibo y la violencia descarnada de la desesperanza, el film brasileño, pese a su crudeza, parece optar por la fórmula de la cordialidad, por la dialéctica del malandrinaje. Aunque no puede vender su maní, Sujinho termina encontrando una madre que todavía no sabe que perdió al hijo biológico, Jorge, en un accidente de tránsito tratando de escapar de la golpiza de la que era objeto. Waldomiro y el "bahiano", en tanto, se conocían del Nordeste, razón por la cual la tensión dramática del posible enfrentamiento se resuelve en carcajada "carnavalesca" durante la coronación de Alice como reina de la escuela de samba "Unidos de Cabuçu". Los acordes esperanzadores de "A voz do morro" culminan la escena y la película para recordar que la alegría del samba sublima el sufrimiento porque es la "melodía de un Brasil feliz".

Como muestra Rio, 40 graus, muchos de los favelados de Río de Janeiro fueron históricamente migrantes rurales, como los soldados bahianos que tras la matanza de Canudos se instalaron en el "Morro da Provicência", llamado popularmente "Morro da Favela", dando origen a la denominación de los caserones irregulares de los cerros. El fin definitivo de la esclavitud en 1888 y el consecuente tránsito de la economía de plantación a un capitalismo orientado a la industrialización hizo aparecer nuevas favelas en la capital Río de Janeiro ocasionando "un crecimiento demográfico extremadamente rápido (fruto de migraciones internas y extranjeras)" (Abreu y Vaz 482). La 
reforma arquitectónica neoclásica de Pereira Passos reubica, a partir de 1904, muchas favelas de la zona central en la zona sur, connotando socialmente el lugar geográfico de los cariocas como "moradores do morro" o "moradores do asfalto". Así, "[d]e un inicio discreto, la favela impuso su presencia efectiva en el espacio urbano y en el imaginario de Río de Janeiro a partir de los años 20" (Lessa 296), siendo por primera vez registrada oficialmente en un plano urbano a fines de esa década por el arquitecto francés Alfred Agache. Los migrantes rurales, que según diversos autores son principalmente nordestinos, transportaron a la ciudad el hambre insatisfecho en el espacio rural: "Las olas de recién-llegados multiplicarían nuevos puntos de concentración de pobreza" (293). Waldomiro, personaje de Nelson Pereira dos Santos, es un migrante antiguo de Bahia que al final de la película se encuentra con el "bahiano", migrante recién llegado, reconociéndolo de su lugar de origen. Esta coterraneidad salva al "bahiano" de un posible crimen pasional relacionado con Alice, en tanto se infiere que la miseria urbana de los cinco niños "moradores do morro" es legado de la jerarquización social impuesta por el sistema agrario esclavista, que en la ciudad "moderniza" sus formas de exclusión según los acomodos seculares de la matriz de poder colonial que Aníbal Quijano e Immanuel Wallerstein denominan colonialidad $^{4}$.

Si hubiera tenido oportunidad de llegar a una ciudad grande, la familia sertaneja compuesta por Fabiano, Sinha Vitória y los dos niños habría formado parte de esta migración interna que desde el siglo XIX en adelante engrosó los cordones de pobreza alrededor de las grandes ciudades brasileñas. Su vulnerabilidad, no obstante, les impide alcanzar esta meta de Sinha Vitória, obligándolos a un peregrinar perpetuo por los estériles paisajes del sertão nordestino. Es su destino, escrito en la novela Vidas secas (1938) de Graciliano Ramos, uno de los exponentes más notables del regionalismo y la "Novela social de 1930". Según Antonio Candido, los romancistas de 30 comparten el "marco histórico" (181) de la represión político-ideológica del Estado Novo, la polarización política de la vida pública y la atención prestada por la izquierda a los éxodos rurales y la miseria campesina-agudizados

\footnotetext{
En el ensayo "La americanidad como concepto, o América en el moderno sistema mundial", los autores señalan: "La colonialidad se inició con la creación de un conjunto de estados reunidos en un sistema interestatal de niveles jerárquicos. Los situados en la parte más baja eran formalmente las colonias. Pero eso era sólo una de sus dimensiones, ya que incluso una vez acabado el status formal de colonia, la colonialidad no terminó, ha persistido en las jerarquías sociales y culturales entre lo europeo y lo no europeo" (584).
} 
en el Nordeste por las sequías del sertão. Escritores como José Américo de Almeida (A bagaceira 1928), Rachel de Queiroz (O quinze 1930), José Lins do Rego (Bangüê 1934) y Jorge Amado (Mar morto 1936) intentan hacer visibles las problemáticas de un Brasil rural demasiado apartado del pregón modernizador de Getúlio Vargas, cultivando una narrativa menos preocupada de la experimentación formal del modernismo y más atenta a la cotidianidad de las clases populares. Candido explica que a partir del regionalismo, el optimismo artístico por habitar un "país nuevo", se transformó en un pesimismo político por pertenecer a un "país subdesarrollado" (140). Analizando las narraciones regionalistas, Alfredo Bosi las divide en "novelas de tensión mínima" - como las de Jorge Amado-y "novelas de tensión crítica" (392) -como las de Graciliano Ramos. Vidas secas representa crudamente la precariedad alimenticia, lingüística, económica, habitacional, social de los habitantes del sertão, con signos de humanidad que -como los vitalesestán en vías de extinción -en tanto herederos modernos del sino miserable de los seguidores de Antonio Conselheiro. En una de las primeras escenas de la novela, el narrador omnisciente describe el fin del papagayo, una de las mascotas de la familia: "Pobre, murió en la arena del río, donde habían descansado, a la orilla de una poza: el hambre había apretado demasiado a los retirantes y por allí no existía señal de comida" (11). La ejecutora de la muerte, Sinha Vitória, "había resuelto de repente aprovecharlo como alimento y se había justificado diciéndose a sí misma que era mudo e inútil”.

La sequía y el hambre del sertanejo, cuidadosamente traducidos a una lacónica "estética literaria" por Graciliano Ramos, es hecha imagen por los cineastas de la primera fase del Cinema Novo. Vidas secas (1963), película de Nelson Pereira dos Santos, inspira a Glauber Rocha para escribir su manifiesto "Estética del hambre" (1965), donde describe el nuevo cine brasileño como poblado de "personajes sucios, feos, descarnados" que están "comiendo tierra, ... comiendo raíces, ... robando para comer" (en Marino 71). En diálogo con el neorrealismo italiano, Pereira dos Santos utiliza el blanco y negro para aludir a la veracidad del documental y, como en Rio, 40 graus, saca la cámara al aire libre para filmar no las vidas crudas de la ciudad sino las vidas secas del sertão -sin miedo a salirse del encuadre o a saturar de luz tomas al sol abrasante. Vidas secas aviva el debate sobre la reforma agraria con un realismo que evita la música extra-diegética y la perfección fotográfica. El narrador omnisciente y el discurso indirecto libre de la literatura es traducido a una cámara en mano que camina cerca de los retirantes y a primeros planos que remarcan su aflicción. La presencia del 
bestiario, aunque puede vincularse a la imagoteca alegórica de Luis Buñuel, cumple una función mimética donde animales y personas, por enfrentarse en igualdad de condiciones a una naturaleza hostil, confunden sus lenguajes de gruñidos zoomorfos y gestos antropomorfos. Esta igualación del hombre al animal lleva a la construcción de la mayor violencia del film: por un desplazamiento metonímico, la cruda muerte de los animales convierte el deceso en una presencia latente que de un momento a otro puede alcanzar a Fabiano y su familia. Por lo mismo, el viaje de los retirantes se sugiere comparable al deambular salvaje del ganado nordestino que instintivamente busca sobrevivir al rigor del sertão; el consejo de Fabiano: "Vai gado, vai para onde tem pasto", se lee como alegoría de la propia vida, como máxima existencial del sertanejo. La elusiva humanidad de Fabiano y su familia, traída a colación por Sinha Vitória en momentos de desesperación -"Você é um bicho, Fabiano!"-, pareciera situarse siempre al final de un viaje, como la sequía, interminable. La novela y la película concluyen con un asomo de esperanza en la nutrición espiritual de la palabra solidaria, creadora de comunidad -acaso la única instancia, en la visión de Graciliano Ramos, de restituir la humanidad a los marginados de su país.

En el marco de las disputas de poder en el campo cultural del Brasil moderno, resulta escandaloso que el hambre denunciado por la literatura regionalista de 1930 y la fase optimista del Cinema Novo haya sido "censurado" por el régimen militar. Mientras la política salarial impuesta al inicio de la dictadura en 1964 aumentó la desigualdad económica, la pobreza extrema y la desnutrición de la población -afectando ésta a 13 millones de brasileños en la década de 1970-, el gobierno "eliminó" el problema erradicando la palabra "hambre" de los medios de comunicación. La ansiedad por el control del campo cultural se observa también en la censura a la producción musical de artistas como Caetano Veloso, Gilberto Gil y Chico Buarque. Antes del Acto Institucional No. 5, la canción "Alegría, alegría" (1967) de Veloso fue censurada por versos como: "Por entre fotos e nomes/ Sem libros e sem fuzil/ Sem fome, sem telefone,/ No coração do Brasil”. En 1938, el Decreto Ley No. 399 había establecido que el salario mínimo debía cubrir las necesidades básicas de alimentación de una familia, pero en 1964, mientras la agricultura se reorganizaba para satisfacer el mercado internacional, el salario mínimo dejó de ser reajustado según el aumento del costo de vida. Aunque el hambre brasileño data del inicio de la Colonia -como indica Josué de Castro en obras como Geografia da fome: A fome no Brasil (1946) y Geopolítica da fome (1951)-, la nueva distribución mundial del poder auspiciada por el capitalismo 
corporativista agudizó el problema con la introducción de políticas económicas que prepararon el terreno para el neoliberalismo. No está de más mencionar que el director del Programa Mundial de Alimentos, Daniel Balaban, aclaró a propósito de la eliminación de Brasil del mapa mundial del hambre en 2014, que el país "nunca tuvo problemas para producir alimentos" porque "[1]a producción brasileña da para alimentar la mitad del mundo. [...] El problema es que los más pobres no tenían poder de compra” (en Martins).

\section{REVOLUCIÓN Y POLÍTICA: DE LA MILITANCIA ARTÍSTICA A LA APROPIACIÓN DICTATORIAL}

[...] ele sabia que capiau de testa peluda, com o cabelo quase nos olhos, é uma raça de homem capaz de guardar o passado em casa, em lugar fresco perto do pote, e ir buscar da rua outras raivas pequenas, tudo para ajuntar à massa-mãe do ódio grande, até chegar o dia de tirar vingança.

A hora e vez de Augusto Matraga (1946), João Guimarães Rosa.

Un destino como el de Fabiano es lo que el cangaceiro (bandido justiciero del sertão) busca evitar a riesgo de condenar su alma. Hacia el final de Deus e o diabo na terra do sol (1964), film de Glauber Rocha, el cangaceiro Corisco, amigo del legendario Lampião, le confiesa al campesino Manoel -incorporado al cangaço como "Satanás": "tengo miedo de quedarme triste y solo, como el ganado vagando al sol". El miedo a exponerse a los rigores del paisaje geopolítico del sertão hace del cangaço (vida de bandidaje) una alternativa de supervivencia en la que el sujeto toma las riendas de su destino enfrentando la hostilidad ambiente con una violencia aún mayor. La película de Rocha, emblemática del Cinema Novo y de la geopolítica del sertão de la primera mitad del siglo $\mathrm{XX}$, muestra las posibilidades que tiene un campesino de escapar a la opresión del latifundio y la sequía: Dios y el diablo. La primera alternativa, fe pagana e histérica que Rocha encarna en el líder carismático Sebastião, es explorada por Manoel en la primera parte de la película. Escapar del hambre es el móvil y Sebastião promete satisfacer no solo las necesidades espirituales de los sertanejos, sino principalmente las estomacales, anunciando el advenimiento de un paraíso terrenal:

Ahora yo digo: al otro lado de allá, de este Monte Santo, existe una tierra donde todo es verde. Los caballos comiendo las flores, y los 
niños bebiendo leche en las aguas del río. Los hombres comen el pan hecho de piedra y el polvo de la tierra se convierte en harina. Existe agua y comida, existe la abundancia del cielo. Y todos los días, cuando el sol nace, aparece Jesús Cristo y la Virgen María, San Jorge y mi San Sebastián.

Como hiciera Antonio Conselheiro a finales del siglo XIX, anunciando que el sertão se haría mar, y que el mar se haría sertão, Sebastião alimenta las esperanzas de cientos de hambrientos que, carentes de toda opción, ansían creer en sus profecías para algún día cultivar comida en el sertão y así, como dice Sinha Vitória de Vidas secas, convertirse en gente. Manoel, quien matara al terrateniente que le robó su escaso alimento, ofrece sus servicios al nuevo Santo popular: "Estoy condenado, pero soy valiente. Entrego mi fuerza a mi Santo... para liberar a mi pueblo". Como muestra esta declaración, la liberación del pueblo adquiere, en el espacio del sertão, connotaciones políticas y religiosas siempre entrelazadas. Junto con alegorizar estos fenómenos, Rocha introduce el cuestionamiento político de la opción de la fe justiciera a través de Rosa, esposa de Manoel, cuya lucidez inicial le permite notar que el fervor religioso deviene histeria colectiva desatada por el hambre y la miseria. Al ver que Manoel está cayendo en el delirio ejecutando violentos ritos ordenados por Sebastião, Rosa asesina al Santo iniciando con su marido una vida de retirantes. En ese vagar como ganado al sol, encuentran al diablo. Esta segunda opción redentora involucra a Rosa y a Manoel con Corisco, cangaceiro apodado diabo louro que pese a la muerte de su amigo Lampião decide seguir en el cangaço "para acabar con lo que está mal, vengando mi sufrimiento, haciendo justicia". Su justicia implica acabar con la gula de quienes están "comiéndose al pueblo para engordar al gobierno de la República" -rebeldía que propicia la aparición del jagunço (asesino a sueldo) Antonio das Mortes, "matador de cangaceiro[s]" como Lampião y otros bandidos sertanejos. Personaje complejo, Antonio comparte sus reflexiones morales cuando, a instancias del obispo, acepta matar a Corisco, último cangaceiro del sertão. En conversación con el ciego, suerte de juglar que narra y fabula las historias del sertão, Antonio dice que él no mata por dinero, afirmando: "no puedo vivir tranquilo con esta miseria".

Antes de ser herido de muerte por Antonio, Corisco proclama el carácter político-religioso de su lucha para enfrentar "al dragón de la riqueza" que encarnan los latifundistas y el gobierno, señalando al mismo tiempo que no siente temor porque "si muero, nace otro" y porque "quien nunca puede morir es San Jorge, el santo del pueblo". La fe de Rocha en la lucha de clases se 
trasluce en la máxima de Corisco: "hombre en esta tierra sólo tiene valor cuando toma las armas para cambiar el destino; no el rosario... sino el rifle, el puñal". Como la favela en el filme inicial de Nelson Pereira dos Santos, el sertão alcanza su máximo simbolismo ético en la representación estética del Cinema Novo. Aunque tratados por un regionalismo literario distinguido por la reivindicación de las clases populares -y que en la prosa de Guimarães Rosa alcanzan, con la sofisticación del lenguaje, ribetes míticos-, el traspaso a la pantalla grande de figuras justicieras como el Santo y el cangaceiro cristalizó su presencia en el imaginario popular en tanto agentes simbólicos de la revolución local. Como productos del pueblo brasileño, el Santo, el cangaceiro y los niños de la calle de las grandes ciudades debían ser, desde la lógica de la lucha de clases, los impulsores naturales de la liberación -aunque fuese desde el espacio simbólico de la literatura y el cine. De allí que Rocha proclamara en 1965 la violencia como única fórmula artística capaz de liberar al pueblo, al hambriento, al colonizado. En su manifiesto "Estética del hambre", Rocha dice que "el comportamiento normal de un hombre hambriento es la violencia", razón por la cual la "estética de la violencia antes de ser primitiva es revolucionaria" porque con ella "el colonizador se da cuenta de la existencia del colonizado" (cit. en Giménez 5). Al mostrar los delirios sangrientos de Sebastião y los crímenes vengativos de Corisco, Rocha busca sentar un precedente simbólico de justicia cinematográfica haciendo pasar al pueblo de víctima de una violencia colonial histórica a agente de una violencia descolonial simbólica. "[E]ste cine de la indignación y de la cólera” fue consecuentemente considerado, por críticos como Román Gubern, "la más cabal expresión en clave poética del drama del Tercer Mundo que ha asomado hasta hoy en las pantallas" (cit. en Giménez 2).

Deus e o diabo na terra do sol fue estrenada en junio de 1964, dos meses después del inicio de la dictadura en Brasil. No es extraño que, ante la fuerza simbólica del Cinema Novo, el gobierno haya buscado controlar el campo cultural mediante la apropiación del léxico redentor de las izquierdas, declarándose una fierísima "batalla simbólica". En el Acto Institucional No.1, proclamado el 9 de abril de 1964, los generales golpistas que derrocaran el gobierno electo de João Goulart legitimaron su destitución aludiendo al carácter soberano de la voluntad del pueblo expresada en la revolución:

La revolución se distingue de otros movimientos armados por el hecho de que en ella se traduce, no el interés y la voluntad de un grupo, sino el interés y la voluntad de la Nación. La revolución victoriosa se inviste en el ejercicio del Poder Constituyente. Éste se manifiesta 
por la elección popular o por la revolución. Ésta es la forma más expresiva y más radical del Poder Constituyente. Así, la revolución victoriosa, como Poder Constituyente, se legitima por sí misma. [...] Los Jefes de la revolución victoriosa, gracias a la acción de las Fuerzas Armadas y al apoyo inequívoco de la Nación, representan el Pueblo y en su nombre ejercen el Poder Constituyente, del cual el Pueblo es el único titular [...]

Desde el triunfo de la Revolución cubana en 1959, la estrategia de apropiación de cierta jerga movilizadora de masas venía siendo adoptada por las políticas de la Alianza para el Progreso, programa creado por el presidente John Kennedy en 1961 para "ayudar" al desarrollo de América Latina por caminos alternativos al de la revolución socialista. Así, mientras los militares eran entrenados en métodos de tortura en la Escuela de las Américas y los economistas eran "deslatinoamericanizados" y mercantilizados en la Universidad de Chicago, la audiencia del pregón de la Alianza para el Progreso fueron los sectores políticos moderados encabezados por Juscelino Kubitscheck en Brasil -cuyo lema era "50 años de progreso en 5 años de gobierno"- y Eduardo Frei Montalva en Chile-que adoptó la consigna "Revolución en libertad" ". La carga populista de los militares brasileños líderes de la "revolución victoriosa" propagó la confusa idea de que el Ejército estaba por entonces defendiendo los intereses del pueblo y no los de un capitalismo corporativista temeroso del avance comunista. En este contexto podemos localizar las polémicas declaraciones de Glauber Rocha sobre el general Golbery do Couto e Silva, entrenado en la Escola Nacional de Guerra -institución creada en 1949 y alineada con la National War College de Estados Unidos-, uno de los organizadores del golpe de Estado de 1964 y jefe de gabinete de Ernesto Geisel. En una carta a Zuenir Ventura de 1974, Rocha señala que, junto con el antropólogo Darcy Ribeiro, Golbery es "uno de los genios de la raza" (en Lopes).

La broma de la ditablanda para referirse al régimen militar brasileño acabó en diciembre de 1968 con el Acto Institucional No. 5, instrumento que dio poderes extraordinarios al presidente, suspendió garantías constitucionales y suprimió las actividades del Poder Legislativo por cerca de un año. Esta medida respondía a la acusación del diputado Márcio Moreira Alves sobre 
que el ejército era un escondrijo de torturadores. Del lado de las izquierdas, esta medida se tradujo en la intensificación de las guerrillas en el campo y la ciudad. Este cambio de escenario político al final de la década de 1960 llevó a Glauber Rocha no solo a un exilio forzado por falta de financiamiento para sus filmes, sino también a reflexionar sobre caminos alternativos para la liberación del pueblo. En la película Antonio das Mortes (1969) aparecen variables que complejizan las aporías tradicionales - pobres vs. ricos, proletariado vs. burguesía, campesinado vs. oligarquía, colonizado vs. colonizador- y que tienen que ver con la introducción de monopolios estadounidenses que anuncian un modelo económico donde el hambre y la miseria serán redimidos por los créditos de consumo. Antonio das Mortes continúa no solo la disyuntiva ética del jagunço impulsándolo a tomar el lado del oprimido, sino que lleva al extremo el examen del fervor popular retomando la leyenda de San Jorge, el santo del pueblo. De allí que la película se conozca también como $O$ dragão da maldade contra o santo guerreiro. Tal como anunciara Corisco antes de morir, otros cangaceiros nacerían después para vengar al pueblo. Por ello, la aparición de Coirana, heredero de Lampião, impulsa a Antonio das Mortes a averiguar si es verdad que todavía existen cangaceiros en territorio brasileño. En una de las primeras escenas, el profesor enseña a los niños del pueblo las fechas importantes de la historia nacional, como la independencia (1822), la abolición de la esclavitud (1888), la declaración de la república (1889) y la muerte de Lampião (1938). En verso, Coirana se declara su seguidor: "quiero ver aparecer los hombres de esta ciudad/ el orgullo y la riqueza del dragón de la maldad/ hoy en día yo me voy/ pero un día voy a regresar/ y ese día sin piedad/ ni una piedra va a restar/ porque la venganza tiene dos cruces/ la cruz del odio y la cruz del amor/ tres veces rece el padre nuestro ¡Lampião nuestro señor!” Según Coirana aclara más adelante, él se hace cangaceiro para cumplir la voluntad de Lampião, quien señalara: "quiero dinero para mi miseria/ quiero comida para mi pueblo/ si no se atiende mi pedido/ voy a volver aquí de nuevo".

La introducción de otras variables en la geopolítica del sertão se sugiere con el personaje del Delegado Matos, quien seduce a la mujer del coronel Horácio mientras intenta aprovecharse de la senilidad y ceguera de éste. El pragmático Matos busca eliminar a Coirana convocando a Antonio das Mortes y no a la policía - evitando así a la prensa- para realizar ciertos planes que explica al Coronel: "quiero instalar una industria aquí, con gente del sur que va a poner dinero, que va a invertir, que exige orden. Necesito acabar con esa fama de violencia en el Nordeste, y que después venga la Reforma 
Agraria para acabar con los conflictos”. El Coronel se enfurece: “¿Reforma Agraria? [...] Yo no voy a dividir mi tierra con esos miserables. ¿Está loco? ¿Yo dividir mi tierra con esos flojos? El gobierno se está volviendo loco. [...] Yo no quiero saber de estadounidenses, de Reforma Agraria, de industria, de ninguna desgracia. Sólo quiero saber de mis vacas..." Al contrastar las visiones de Matos con las del Coronel, no es difícil deducir el contenido de la "revolución" a la que se refieren los militares. Mientras juegan billar, Matos le dice al profesor: "Los que van a salvar este país son los estadounidenses", a lo que éste responde: "¿Van a salvar este país o el bolsillo de quien los recibe?”. Este tránsito de paradigmas de poder genera la confusión del profesor cachaceiro, encarnación del intelectual derrotado: "yo ya perdí todas [las guerras], las del miedo, de la cobardía, hasta al enemigo perdí de vista". Reflexiones similares acercan a Antonio das Mortes a Doña Santa y los beatos. Buscando su propia redención, Antonio le exige al Coronel repartir alimentos y tierras al pueblo, recado que envía con Matos. Antonio confiesa: "después que vi aquella gente de cerca, sentí una cosa como nunca sentí en la vida", y explica: "hace mucho tiempo que estoy buscando un lado donde quedarme. Ahora voy a quedarme del lado de allá, bien cerca de la Santa [porque] ya estoy entendiendo quiénes son los enemigos". El profesor y el matador de cangaceiro[s] se unen para combatir al dragón de la maldad, y así "vengar a la mitad de[1] sertão denigrado", pero finalmente el Nego Antão da el golpe de gracia materializando la justicia de San Jorge. Con la muerte del coronel Horácio, no es el criollo sino el africano quien venga siglos de opresión colonial contra las razas subalternizadas.

Retomando los modelos de interpretación de la cultura brasileña, tanto Deus e o diabo naterra do sol como Antonio das Mortes proponen una dialéctica de la marginalidad para resolver los conflictos sociales mediante el enfrentamiento directo y violento a las instituciones generadoras de injusticia. Sin embargo, la conversión de Antonio das Mortes de jagunço a cangaceiro (Amar Rodríguez 169) tiene un sombrío final al estilo de los Spaghetti Westerns, donde el bandido justiciero camina por la carretera hacia un horizonte incierto, iluminado en el film de Rocha por el "sol" plástico de la petrolera anglo-holandesa Shell. Esta ambigüedad refleja quizás la angustia del propio Rocha, quien apuesta con más fervor que razón al cambio de posición del hombre armado a sueldo, de los militares, hacia el lado de la utopía popular. En el mismo texto donde compara al general Couto e Silva con Darcy Ribeiro, Rocha afirma: "creo que [Ernesto] Geisel tiene todo en sus manos para hacer de Brasil un país fuerte, justo, libre. Estoy seguro incluso de que los militares son legítimos 
representantes del pueblo" (en Lopes). Desde esta perspectiva, Antonio das Mortes implica una sacudida a los cimientos de la lucha de clases en tanto el pueblo parece no ser el actor más adecuado para llevar a cabo la revolución -duda emblemática que tal vez propició el golpe final contra la lucha social armada pues, según declaración a la revista $I s t o E ́$ de un general ligado a Geisel, en 1973 se optó por el exterminio: “o matábamos a todo el mundo, o esas guerrillas nunca tendrían fin" (en Comissão da Verdade do Estado de São Paulo). La experiencia brasileña fue quizás la escuela de dictaduras posteriores, como la chilena y la argentina, que optaron por el exterminio desde el primer día - e incluso antes.

\section{DERROTA Y MERCADO: REGRESO PARÓDICO Y CONSUMISTA AL HOMBRE CORDIAL}

Depois de muito refletir, Macunaíma gastara o arame derradeiro comprando o que mais o entusiasmara na civilização paulista. [...] Não possuía mais nem um tostão do que ganhara no bicho porém lhe balangando no beiço furado pendia a muiraquitã. Macunaíma (1928), Mário de Andrade.

El desencanto de Glauber Rocha en torno a los actores tradicionalmente identificados como protagonistas y agentes de la lucha de clases, el pueblo y el intelectual comprometido, había sido anunciado en un film anterior a Antonio das Mortes. Como primera reflexión en torno a la dictadura militar brasileña, Terra em transe (1967) es una alegoría de la incapacidad del político de izquierda para mantener sus promesas electorales, de la inconsecuencia del intelectual comprometido ante la imposibilidad de la revolución, de la precariedad del pueblo en tanto actor social, de la corrupción del político de derecha para perpetuar sus privilegios y del oportunismo de compañías internacionales para introducir sus negocios al Tercer Mundo. El golpe de Estado de Porfirio Díaz en Eldorado provoca la caída del gobernador populista Felipe Vieira, apoyado por el poeta y periodista Paulo Martins, escena donde chocan las dos "fórmulas" brasileñas de resolución de conflictos: la dialéctica del malandrinaje de Vieira: "No quiero derramamiento de sangre. [...] La sangre del pueblo es sagrada. [...] Es una lucha inútil, seremos aplastados"; y la dialéctica de la marginalidad de Paulo: "¡Ahora tenemos que ir hasta el fin! [...] La sangre no tiene importancia. [...] ¡No puede traicionarnos!”. En el 
discurso de dimisión, Vieira le dicta a su asistente Sara: "Siendo así consumado nuestro destino frente a las grandes decisiones nacionales, entregamos nuestro gobierno al supremo poder federal seguros de que resistir podrá, quizás, provocar una guerra fraticida entre inocentes. Entrego mi camino a Dios y espero que, una vez más Dios bendiga a Eldorado con su gracia divina, llevando a los corazones humanos el amor que todo lo une". El malandrinaje de Vieira preserva el statu quo ante la impotencia de Paulo, quien se aferra a la utopía: “Necesitamos resistir, resistir, y yo necesito cantar!” La herida de muerte inaugura la cáustica reflexión del intelectual comprometido sobre la política partidista y el pueblo: "Ya no es posible esta esperanza dorada en el gobierno. Ya no es posible esta marcha de banderas con la guerra y con Cristo en el mismo lugar. [...] La ingenuidad de la fe. La impotencia de la fe". Varios flash backs muestran el momento en que Paulo deja de apoyar a Díaz, en uno de los cuales el poeta es reprochado: "Los extremistas crearon una mística del pueblo. ¡Pero el pueblo no vale nada! El pueblo es ciego y vengativo". Luego, ante las cámaras de televisión, el pueblo habla a través de Jerónimo: "El país está en una crisis y lo mejor es aguardar la orden del presidente”, siendo interrumpido por Paulo: “¿Ven lo que es el pueblo? ¡Un imbécil!". Pero cuando otro poblador se atreve a decir: "El pueblo soy yo, que tengo siete niños, ¡y no tengo donde vivir!”, la reacción de la opinión pública no se hace esperar: “¡Extremista! ¡Extremista! ¡Extremista!...”

La tragedia de Rocha, callejón sin salida en que el intelectual calma su angustia en orgías mientras el capital internacional interviene la prensa y la política local, no dejó a nadie indiferente: en Brasil la izquierda la condenó por fascista y la derecha la censuró por subversiva, en tanto fue aclamada internacionalmente por su efusión política y artística. A diferencia de las obras de la sección anterior, donde una voz narrativa articulaba metros populares ejecutados por cantores rurales, en Terra em transe la poesía lírico-vanguardista de Paulo, declamada trágicamente por él mismo, refiere su agonía y desilusión de la política y el arte. Robert Stam dice que el film fue erróneamente considerado un apelo romántico al guevarismo, en circunstancias que "está más interesado en desmitificar la política populista que llevó al golpe [brasileño]" (169). En su exhaustivo análisis de 1976, propiciado por el golpe de Estado a Salvador Allende tres años antes, Stam dice que el film es un examen crítico de los arquetipos políticos de la sociedad brasileña y latinoamericana donde se enjuicia tanto a la izquierda como a la derecha por tal derrota: aunque los líderes populistas niegan sus raíces burguesas u oligarcas, el montaje paralelo de las campañas electorales de Vieira y Díaz 
denuncia el autoengaño (170). Asimismo, el reportaje televisivo de Paulo, "Biografía de un aventurero" sobre su mentor Díaz, es un intento infructuoso de "matar al padre" pues el poeta reproduce el desprecio al pueblo que critica en sectores conservadores. Stam explica que con este "carnaval trágico" de la política latinoamericana, Rocha busca "purga[r] su propio romanticismo" (171), actitud que "ya no tiene lugar en un mundo sujeto a convulsiones". Junto a la derrota política, el fracaso doloroso de estéticas revolucionarias como el Romanticismo (dialéctica de la marginalidad), estimula el regreso a la provocación lúdica de la primera fase del modernismo (dialéctica del malandrinaje) encarnada en la estética alegórica de la tropicália. El nuevo amanecer económico, expuesto en Tierra en transe con la invasión de la Explint y en Antonio das Mortes con el sol plástico de la Shell, augura el surgimiento de un nuevo campo cultural cuyo paisaje urbano y rural se nutrirá de bienes materiales y simbólicos que ayudarán a perpetuar la "forma relajada... de lidiar con la injusticia social", forma mediada ahora por el mercado.

En consecuencia, no es raro que Johnson y Stam definan la fase "tropicalista" final del Cinema Novo como cultora de un "lenguaje codificado de rebelión" (40) ya que después del Acto Institucional No. 5 los artistas enfrentaron una censura militar tiránica. El camino que el cineasta Joaquim Pedro de Andrade encontró para evadirla fue la apropiación y resignificación de la estética lúdico-subversiva de escritores modernistas como Mário de Andrade y Oswald de Andrade. Su película Macunaíma (1969), basada en la novela homónima de Mário, constituye un ecléctico collage de expresiones intermediales tomadas de la surtida "iconósfera" (Cohen-Séat 1959) brasileña de fines de la década de 1960: su escenografía está influida por la instalación artística "Tropicália" (1967) de Hélio Oiticica, el vestuario dialoga con el pop art y la psicodelia, la decoración muestra la presencia alegórica y "ornamental" de la última tecnología, y la banda sonora remite a las décadas de 1920 y 1960, incluyendo tangos, boleros, himnos del músico vanguardista Heitor VillaLobos y canciones de la Jovem Guarda. Aunque este colorido pastiche pop revela el voraz consumo que Joaquim Pedro de Andrade hace del mercado de bienes materiales y simbólicos del nuevo campo cultural, conviene examinar su uso de la globalización y la música popular para hacer pasar a Ci de guerrera literaria a guerrillera cinematográfica, desplazándola desde el espacio amazónico mítico donde la imaginó Mário de Andrade, hasta el espacio urbano histórico del Brasil de la dictadura militar.

Un efecto planetario de la globalización cultural estimulada por el capitalismo global es, como señala el francés Guy Debord, la emergencia 
de una "sociedad del espectáculo" cuyo elemento aglutinador son las imágenes convertidas en paradigma epocal. El espectáculo es "una visión del mundo que se ha objetivado" (9) y que, por ello, legitima la alienación promovida por la economía. En diálogo con Walter Benjamin, creemos que la reproducción masiva de ciertos "íconos" del star-system adjudicó cierta "auralidad" a las estrellas de cine del siglo XX que, devenidas objetos de consumo, estimulan -si seguimos la lectura de Debord- la alienación del público por el encandilamiento emanado de la espectacularidad del medio. Sin embargo, existe otra dimensión que la masificación confiere a figuras ligadas no al mundo del espectáculo sino, por ejemplo, de la política y las artes. Es el caso de la multiplicación ad infinitum de la imagen de Ernesto "Che" Guevara, la cual, si bien posee una dimensión vinculada con la alienación capitalista - como cuando Paris Hilton usa la camiseta del Che-, también provoca la mitificación del ícono en tanto sinécdoque de valores en peligro de extinción por el avance del propio capitalismo. Según muestra el documental Una foto recorre el mundo (1981) de Pedro Chaskel, que analiza los efectos de la reproducción masiva de la imagen que Alberto Korda captó del revolucionario en 1960, la mediación de la fotografía contribuyó a divinizar su imagen convirtiéndolo en un mito moderno. Y si concordamos con que el "espectáculo es la reconstrucción material de la ilusión religiosa" (Debord 14), podemos señalar que la mediatización del guerrillero convirtió a esta figura heroica en el ser mítico de la modernidad, admirado por enfrentar al monstruo más grande de la modernidad global: el capitalismo estadounidense. Por ello, a diferencia de la alienación victimizante sugerida por Debord, creemos que el sistema de celebridades comodificadas contiene, como efecto boomerang, su propio antídoto anti-alienación por la masificación de los agentes de su transgresión. En este contexto, si bien Joaquim Pedro de Andrade añade este resplandor aural a la representación cinematográfica de Ci tornándola objeto de consumo y mito moderno, no estamos seguros de hasta qué punto este gesto es suficientemente subversivo ${ }^{6}$.

\footnotetext{
Interpreto la idea de "aura" de Walter Benjamin no solo como una experiencia estética emanada del arte clásico -es decir, del arte no reproducible mecánicamente-, sino también pensando en Marshall McLuhan y su propuesta de que "el medio es el mensaje" (186). Pese a que Benjamin dice que "[t]he cult of the movie star, fostered by the money of the film industry" no preserva "the unique aura of the person but "the spell of the personality" (231), me parece que el resplandor de la proyección cinematográfica le confiere a la estrella una luminosidad "aural" que provoca un efecto hipnótico en el espectador, más por las
} 
A diferencia de la novela, la película sitúa la soberanía de la "Madre de la Selva" en una ciudad dominada por la burguesía -representada por el gigante Venceslau Pietro Pietra-y a cada momento boicoteada por las guerrillas urbanas lideradas por Ci. Su trabajo es hacer explotar edificios de gobierno, siendo diestra en el manejo de las armas, rasgo que la erotiza a ojos de Macunaíma y los espectadores debido al sexualizado tratamiento del personaje. No extraña que el tema escogido por Joaquim Pedro de Andrade para caracterizarla pertenezca a la Jovem Guarda, movimiento surgido de estímulos globales como los Beatles, la psicoldelia, el hipismo y las revoluciones sexuales. La canción "É papo firme" (1966) de Roberto Carlos habla de un nuevo tipo de femineidad, encarnado por una mujer fuerte que no se deja dominar y a la que, además, le gusta andar a la moda:

Essa garota é papo firme, é papo firme, é papo firme

Se alguém diz que ela está errada

Ela dá bronca, fica zangada

Manda tudo pro inferno

e diz que hoje isso é moderno.

Son los versos que anuncian la entrada triunfal de $\mathrm{Ci}$ en la película, metralleta en mano y en medio de una balacera, mientras Macunaíma y sus hermanos pasean por São Paulo. Así, en un primer nivel simbólico, Ci es representada como objeto de consumo/deseo promovido por la auralidad espectacular del guerrillero, integrado al star-system global en la segunda mitad del siglo $\mathrm{XX}$. Pero el peligro de su trabajo la arrastra a ella y al hijo de su relación con Macunaíma a morir como mártires, desplegándose con ello el segundo nivel simbólico del personaje: el mito. Cuando Macunaíma la recuerda con nostalgia mirando al cielo -porque ella, como en la novela, se torna estrella del firmamento-, él añade una capa de psicodelia a su imagen astral re-bautizándola como "Lu-Ci" -alusión a la canción "Lucy in the Sky with Diamonds" (1967) de los Beatles. El tema no se escucha, pero el espectador globalizado sin duda imagina a $\mathrm{Ci}$ "in a boat on a river/ with tangerine trees and marmalade skies [...]" Ci se convierte en un personaje mítico, como en la novela de Mário de Andrade, pero en un mito psicodélico cuya muerte

características del medio de comunicación -"la luz eléctrica es información pura” (McLuhan 186) - que por el contenido o "discurso" transmitido. 
física, al volverla materialmente inalcanzable pero masivamente visible, sella su ambigua calidad de objeto del deseo y objeto de consumo.

Es indudable que la representación de Ci como sexo fuerte implica una construcción femenina revolucionaria por parte de Joaquim Pedro de Andrade. No obstante, resulta problemático que Macunaíma continúe la tradición patriarcal de dejarse servir por la mujer en el espacio doméstico y que la caracterización femenina retome un nuevo estereotipo de las fantasías masculinas: la dominatrix. El día que Ci va con su hijo a realizar el atentado que termina con sus vidas, ella se viste con un traje de cuero y, mientras programa la bomba y prepara leche para el bebé, un plano general la muestra topless de espalda a la cámara. Además de maltratar a Macunaíma en la intimidad, la participación de $\mathrm{Ci}$ en la película es mínima. Retomando a Debord y su idea de que "[e]l espectáculo constituye el modelo presente de la vida socialmente dominante" (9), podemos interpretar la relación entre Ci y Macunaíma como la realización de la fantasía masculina de poseer al mito del mundo moderno convertido además en "estrella" mediática: la guerrillera atractiva y erotizada como las féminas del star-system hollywoodense, y contraparte desigual del Che, cuya figura es mitificada especialmente tras su muerte en 1968. Ci es el espectáculo de Macunaíma, quien en todo momento mantiene una postura voyeurista de admiración pasiva, reduciendo su agencia a un dejarse alimentar y poseer por ella. Por esta razón, cuando Ci muere se torna un signo contradictorio de la sociedad del espectáculo: Macunaíma la convierte en Lu-Ci (in the sky with diamonds), otorgándole un valor de culto en el espacio atemporal de la cultura popular, valor mítico en tanto estrella del firmamento, pero alienante en la medida en que perpetúa su erotización más allá de la muerte ${ }^{7}$. Este impreciso lenguaje de rebelión usado por Joaquim Pedro de Andrade da cuenta de la existencia de una contracultura subversiva en la época más represiva de la dictadura brasileña, pero también muestra que la subversión mediatizada acaba siendo incorporada al imaginario de la cultura popular de la sociedad del espectáculo. Y en el caso de una mujer, el carácter mítico acaba siendo eclipsado por su carga erótica, representación

\footnotetext{
Walter Benjamin habla del "valor de culto" en relación con las primeras fotografías, retratos que buscaban perpetuar la imagen del ser amado (226). En el caso de "Lucy in the Sky with Diamonds" de los Beatles, el valor de culto para Macunaíma no radicaría en la perpetuación del ser amado mediante su imagen visual, sino mediante la reproductibilidad masiva de este artefacto "auditivo" creado por la música popular anglosajona que, no obstante, gatilla una imagen mental que él relaciona con $\mathrm{Ci}$.
} 
que en última instancia traduce una aproximación no solo carnavalesca sino patriarcal del hombre a la mujer.

Como el héroe de la película de Joaquim Pedro de Andrade, quien aplaca su desencanto por la imposibilidad de ser feliz comprando una serie de electrodomésticos para su hogar en la selva, el pueblo representado por Carlos Diegues en Bye Bye Brasil (1979) sobrelleva la exclusión social mediante el embrujo del consumo. En ambos casos existe una retomada paródica de la tragedia imaginada por Glauber Rocha en Tierra en transe: mientras el intelectual herói do nosso povo es "incapaz de sustentar ningún proyecto político" (Wisnik 2014), el pueblo indígena del mato virgem que los citadinos Lorde Cigano y Salomé, y los sertanejos Ciço y Dasdó encuentran en Altamira, no está preocupado de la utopía revolucionaria sino del jeans de marca y de los nuevos patines:
No Tocatins
O chefe dos parintintins
Vidrou na mina calça Lee
Eu vi uns patins pra você
Eu vi um Brasil na tevê
Capaz de cair um toró
Estou me sentindo tão só

El consumo no cura la frustración de Macunaíma, quien como en la novela es invadido por una melancolía que intenta mitigar con la palabra oral, comunitaria, contándole sus aventuras al papagayo. Tampoco cura la soledad de Ciço -"Estou me sentindo tão só"-, como afirma la canción homónima de la película de Diegues, compuesta por Chico Buarque. Sin embargo, es preciso recalcar el regreso de estas películas a la ambigüedad de la nãoescolha del hombre cordial, esta vez bajo el sol consolador del mercado -capaz incluso de invisibilizar el hambre con la igualación social de la tarjeta de crédito. Tras el final paródico de las utopías en el cine de Joaquim Pedro de Andrade -que llega a adquirir un carácter de homenaje nostálgico en $O$ homem do Pau-Brasil (1982)-, el cine de Carlos Diegues sintomatiza, al final del tropicalismo y de la década de 1970, una ruptura respecto al ideal de cambiar el mundo y un giro hacia el registro de felicidades más íntimas y fugaces -"en esos pocos momentos en que la luz de ese destino se revela en el horizonte, aunque sea por poco tiempo, sorprendemos al mundo con la generosidad y grandeza de nuestras hazañas, con la propuesta de una nueva e inesperada civilización, más humana y fraterna" (Leal y Diegues). Como 
insinúa el Cinema Novo, la muiraquitã de la utopía socialista parece haberse perdido en uno de los recodos de la década de 1960, mientras que la vía chilena al socialismo se percibe como crónica de una muerte anunciada por las transformaciones del campo cultural latinoamericano durante la guerra fría. Como hija de la dictadura chilena, a personas como yo no nos quedan muchos otros ejercicios que el de la nostalgia por una utopía desconocida, aprendida en libros, canciones, fotos y archivos fílmicos en blanco y negro. Pero esta hambre de utopía de las generaciones actuales ciertamente aviva el examen crítico de una época que concentra muchas de las claves del último gran desencuentro de la modernidad en América Latina.

\section{BIBLIOGRAFÍA}

Abreu, Maurício de e Lilian F. Vaz. "Sobre as origens da favela". Anais do IV Encontro Nacional da ANPUR, Salvador (1991): 481-492.

Amar Rodríguez, Víctor Manuel. El cine nuevo brasileño (1954-1974). Madrid: Dykinson Editorial, 1994.

Benjamin, Walter. "The Work of Art in the Age of Mechanical Reproduction”. Illuminations: Essays and Reflections. Ed. Hannah Arendt. New York: Harcourt, Brace \& World, 1968.

Bosi, Alfredo. História concisa da literatura brasileira. São Paulo: Cultrix, 2006.

Bourdieu, Pierre. Las reglas del arte. Barcelona: Anagrama, 1995.

Candido, Antonio. A educação pela noite \& outros ensaios. São Paulo: Editora Ática, 1989.

Cohen-Séat, Gilbert. Problèmes actuels du cinéma et de l'information visuelle. Tome I. Paris: PUF, 1959.

Comissão da Verdade do Estado de São Paulo. Rubens Paiva. Caso Luíz Carlos Almeida. http://www.comissaodaverdade.org.br/caso_integra.php?id=59 Consultado: 20 de octubre de 2014.

Cunha, Euclides da. Los sertones. Caracas: Biblioteca Ayacucho, 1980.

Debord, Guy. La sociedad del espectáculo. Santiago de Chile: Ediciones Naufragio, 1995.

Giménez Soria, Carlos. “Glauber Rocha y el Cinema Nôvo brasileño”. La siega XX N 6 (2008): 1-11. http://www.lasiega.org/entrega6/entrega6_17.pdf. Consultado: 20 de octubre de 2014.

Holanda, Sérgio Buarque de. Raízes do Brasil. São Paulo: Companhia das Letras, 1995.

Johnson, Randal y Robert Stam. Brazilian Cinema. New York: Columbia University Press, 1995.

Leal, Hermes y Carlos Diegues. "Entrevista". Revista de cinema 5. (2000). http://www. carlosdiegues.com.br/artigos_integra.asp?idA=23 Consultado: 20 de octubre de 2014.

Lessa, Carlos. O Rio de todos os Brasis: uma reflexão em busca de auto-estima. Rio de Janeiro: Record, 2005. 
Lopes, Carlos. "Glauber Rocha e a ditadura". O Martelo. Rio de Janeiro. http://omartelo.com/ omartelo22/materia1.html Consultado: 20 de octubre de 2014.

Marino, Alfredo. Cine argentino y latino-americano. Una mirada crítica. Buenos Aires: Nobuko, 2004.

Martins, Rodrigo. “A fome é uma vergonha menos para o Brasil”. Carta Capital. 25 de setembro de 2014. http://www.cartacapital.com.br/blogs/cartas-da-esplanada/uma-vergonha-amenos-4019.html Consultado: 19 de octubre de 2014.

McLuhan, Marshall. Escritos esenciales. Barcelona: Editorial Paidós, 1998.

Ramos, Graciliano. Vidas secas. Rio de Janeiro: Record, 2008.

Ramos, Julio. Desencuentros de la modernidad en América Latina. Literatura y politica en el siglo XIX. Caracas: Editorial el perro y la rana, 2009.

Rocha, João César de Castro. “A guerra de relatos no Brasil contemporâneo. Ou: a "dialética da marginalidade"”. Letras 32. Revista do Programa da Pós Graduação em Letras - PPGL/ UFSM (2006): 23-70.

Rosa, João Guimarães. Sagarana. Rio de Janeiro: Record.Stam, Robert (1976). "Terra em transe". Discurso. Vol. 7, No. 7. São Paulo (1984): 169-181.

Valdés, Juan Gabriel. Pinochet's Economists. The Chicago School in Chile.Cambridge and New York: Cambridge University Press, 1995.

Wallerstein, Immanuel y Aníbal Quijano. "La americanidad como concepto, o América en el moderno sistema mundial”. América: 1492-1992. Trayectorias históricas y elementos del desarrollo 134. UNESCO (1992): 583-591.

Wisnik, José Miguel. "A canção popular no Brasil entre 1964 e 1968”. Conferencia magistral. IX Jornadas Brasileñas. Facultad de Filosofía y Humanidades, Universidad de Chile, 2014. 